\title{
Exploring the Relationship Between Learning Motivation and L2 WTC in an EFL Classroom Among Thai EFL Learners
}

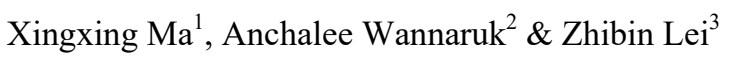 \\ ${ }^{1}$ School of Foreign Languages, Anshun University, Anshun, China \\ ${ }^{2}$ School of Foreign Languages, Suranaree University of Technology, Nakhon Ratchasima, Thailand \\ ${ }^{3}$ School of Foreign Languages, Hunan First Normal University, Changsha, China \\ Correspondence: Xingxing Ma, School of Foreign Languages, Anshun University, China.
}

Received: January 28, 2019 Accepted: June 1, 2019 Online Published: June 3, 2019

doi: 10.5539/elt.v12n7p33 URL: https://doi.org/10.5539/elt.v12n7p33

\begin{abstract}
The present study investigates the relationship between university learners' English learning motivation and their willingness to communicate in English (L2 WTC) in EFL classroom under the big environment of Thailand joining the AEC (ASEAN Economic Community). By applying mixed methods, data is collected and the findings can be summarized as follows. Firstly, the university learners including males and females all have high motivation towards English learning, especially with higher instrumental motivation. Besides, the university learners in total have intermediate level on their willingness to communicate in English in EFL classrooms without significant gender difference. More than $50 \%$ of students are more willing to communicate in English with friends than with teachers for they believe that friends are easier to communicate and understand. Thirdly, university learners' English learning motivation has strong positively correlation with their L2 WTC. In English learning motivation, instrumental motivation has stronger positively correlation with their L2 WTC than integrative counterpart and is better predictor of students' L2 WTC in EFL classroom. These findings have implications for teachers teaching English in EFL context who should take the big environment in society and their distance with students into account, and shed some lights on the research of L2 WTC in the future.
\end{abstract}

Keywords: AEC, foreign language classroom, English learning motivation, L2 WTC, gender

\section{Introduction}

Countries in Southeast Asia, including Thailand, realize the important part of English as a lingua franca for foreign investment, the economy, industry, science, medicine, information and technology, education, and communication since the Association of Southeast Asian Nations (ASEAN) in 1967. One of the statements in the ASEAN Socio-Cultural Community (ASCC) blueprint is to promote the use of English language, because English has become the only working language of the ASEAN. The agreement of the 'Free Flow of Skilled Labor' or 'Mobility of professions in ASEAN community' set out in 2015 would be advantageous to other ASEAN nationals who are more fluent in the ASEAN lingua franca and the international language of science, business, tourism, etc.: English. The English teachers have shown their real concern and awareness in improving the learners' communication skills.

The youngsters are secured under the 2002 Education Act Amendment, guaranteeing them a 14-year free education (National Report, 2004). With this educational scheme, Thai students could learn English as early as the primary level since English had long been made a compulsory subject from primary to high school level. More foreign teachers are employed to teach English in public and private schools in Thailand. Former Minister of Education, Woravat Auapinyakul, launched Thailand's English Speaking Year 2012 program on December 26, 2011, with the purpose of preparing Thai people for the ASEAN Community in 2015. With this initiative program, schools throughout the nation are encouraged to set one day in a week to encourage their students to use English in classroom and outside classroom setting.

The construct of Willingness to Communicate (WTC) is seen as a final step before actual L2 use (MacIntyre et al., 1998). An increase in WTC has been found to produce positive influence on L2 learning and acquisition; L2 learners with high level of WTC are more likely to benefit from communicate language teaching (Ellis, 2004), interact in L2 more frequently (Clement et al., 2003; MacIntyre \& Gardner, 1991; MacIntyre, Baker, Clement, \& 
Conrod, 2001; Peng \& Woodrow, 2010), are more inclined to take risks to communicate in L2 (Oxford, 1997), have more chances for authentic L2 use, then become more active and autonomous learners (Kang, 2005), achieve higher level of language fluency (Derwing, Munro, \& Thomson, 2008), and generally achieve higher language proficiency (MacIntyre et al., 1998; MacIntyre et al., 2001; Yashima, 2002). Accordingly, inspiring WTC in L2 has been suggested by scholars such as Dörnyei (2001) and MacIntyre et al. (1998) as a crucial goal of L2 pedagogy.

Then why is Thai students' English test performance marginally substandard over the past years? (NIETS, 2011: EF English Proficiency Index, 2011). Why do Thai EFL learners appear to be unwilling to communicate in English in classroom and normally avoid communicating in English both inside and outside the language classroom, as shown in the literature (Bennui, 2008; Kamprasertwong, 2010)?

The present study aims to examine possible relationship between L2 learning motivation and L2 WTC among EFL students and then validate the relationship under the ASEAN Community and globalization so as to provide English teachers with knowledge of students' motivation in English learning and their WTC in L2 and suggestions how to facilitate students WTC in teaching practice.

\section{Conceptual Framework}

Firstly, the definitions of L2 learning motivation and L2 WTC were introduced respectively. Then, the focus on the precious studies concerning the relationship between L2 learning motivation and L2 WTC was presented in this section. Finally, gaps were pointed out.

\subsection{Definition of L2 Learning Motivation}

Motivation has been consistently regarded as a critical determinant of language learning and achievement. Motivation is "a process whereby a certain amount of instigation force arises, initiates action, and persists as long as no other force comes into play to weaken it and thereby terminate action, or until the planned outcome has been reached" (Dörnyei, 1998: 118). Sergi (2004) also pointed out that (a) motivation is a process, (b) it involves goals which individuals have in mind and try to attain (or avoid), (c) it requires activity on the part of the individuals, the activities that students engage in are geared toward attaining their goal, and (d) motivated activity is both instigated and sustained. In brief, in the present study the definition of L2 learning motivation includes 1) the goal of learning the language; 2) the effort to realize the goal; and 3) the sustenance of the goal.

\subsection{Definition of L2 WTC}

WTC in L2 refers to "a readiness to enter into discourse at a particular time with a specific person or persons, using a L2" (MacIntyre, Dörnyei, Clément, \& Noels, 1998, p. 547). When presented with an opportunity to use their L2, why do some people choose to speak up, while others remain silent? Some students high in linguistic competence are unwilling to use their L2 for communication, while other students, with only minimal linguistic knowledge, seem to communicate in the L2 whenever possible. These individual differences in communication tendencies play a meaningful role in language-learning outcomes.

In order to make the definition of L2 WTC more suitable for EFL context in the present study, we adapt MacIntyre et al.'s (1998) definition of L2 WTC as "a willingness to enter into communication in spoken way in language classroom with a person or persons, using a L2". As a complex but important component of communicative language teaching and L2 pedagogy (Kang, 2005), WTC can be seen as both a facilitating factor of instructed language learning and a nonlinguistic outcome of the L2 learning process (MacIntyre, 2007). Kang (2005) stated that an increase in L2 WTC in classroom has at least three advantages: (1) L2 learners with high WTC are more prone to use the L2 in authentic communication, which facilitates language learning; (2) these learners have the potential to become more autonomous and make efforts to learn the language through communication without the teacher's help; and (3) these learners can extend their learning experience outside the classroom.

\subsection{Precious Studies on the Relationship Between L2 Learning Motivation and L2 WTC}

Motivation is a construct closely related to L2 WTC. Dörnyei and Skehan (2003) viewed L2 WTC as an extension of the motivation construct. MacIntyre, MacMaster and Baker (2001: 462) postulated that L2 WTC is a variable that "approach(es) the topic of motivation from different directions." Based on the results of factor analysis, they suggested that L2 WTC is strongly related to the motivational process. WTC has also been used as a background variable in Dörnyei and associates' motivation research (Dörnyei \& Kormos, 2000; Kormos \& Dörnyei, 2004).

Gardner's (1985) socio-educational model has been one of the most influential frameworks in motivation and 
second language acquisition research. This model proposes that individual differences in L2 learning can largely be explained by learners' integrative motive/motivation. Integrative motivation is empirically conceptualized to have three components: integrativeness, attitudes toward the learning situation, and motivation. Integrativeness reflects an individual's inclination to interact or identify with the L2 community, which comprises three operational dimensions: integrative orientation, attitudes toward the L2 community and interest in foreign languages. Attitudes toward the learning situation subsume the individual's evaluation of the language teacher and the L2 course. These former two components are perceived to influence the third one: motivation, which is measured by L2 learners' desire to learn the L2, the effort invested and the attitude towards learning.

This model suggests that learners who are attitudinally affiliated with the L2 community will be more motivated to persevere in learning the $\mathrm{L} 2$ in both formal and informal situations.Under this model, research on motivation has investigated its influence on learners' WTC. MacIntyre et al. (2001) and Hashimoto (2002) observed that motivation positively influenced WTC in L2, which resulted in increased L2 communication frequency. That is, students who were more interested in using the $\mathrm{L} 2$ in the classroom were found to display higher motivation to learn the L2. In MacIntyre et al. (2003), WTC correlated very highly with motivation for language learning among students with immersion and other intensive program experiences. Similarly, Peng (2012) determined that motivation to learn the foreign language was linked to learners' WTC. Other studies have identified only an indirect relationship between motivation and L2 WTC. Yashima (2002) also concluded that motivation indirectly influenced WTC through self-confidence.

MacIntyre and Charos (1996) inferred a path leading from L2 WTC to motivation based on Clément's (1980) contextual model in their study utilizing path analysis. This expected path was eventually not statistically supported. Yashima (2002) hypothesised a direct path from motivation to L2 WTC, based on MacIntyre et al.'s (1998) WTC model. This path was also missing in the final model developed using structural equation modelling (SEM). Motivational influence on L2 WTC has, likewise, not been explicitly addressed in qualitative L2 WTC studies (Kang, 2005). Conversely, Hashimoto (2002) replicated MacIntyre and Charos' (1996) study amongst 56 students using SEM and identified a significant path from L2 WTC to motivation. Results of correlation analyses from research into immersion programs (MacIntyre et al., 2002, 2003) also revealed that significant correlations exist between L2 WTC and integrative motivation.

\subsection{Gaps in the Previous Studies}

As for the relationship between L2 learning motivation and L2 WTC, equivocal results have been yielded from previous studies. Those inconsistent results may be attributed to the different participants involved, different methodologies, varying statistical techniques employed and the different learning contexts where studies were conducted, which need further empirical research. In addition, there are few studies concerning the relationship between university students' L2 learning motivation and their L2 WTC in Thai EFL classroom. In order to fin in the gaps, the present study was carried out.

\subsection{Research Questions}

Three research questions were addressed as follows:

1). What is the level of university learners' English learning motivation? Is there any significant difference on the levels of their English learning motivation between male and female students?

2). What is the level of university learners' L2 WTC in an EFL classroom? Is there any significant difference on the levels of their L2 WTC between male and female students?

3). What is the relationship between university Learners' English Learning Motivation and their L2 WTC in an EFL Classroom?

\section{Methods}

\subsection{Participants}

This study was conducted at the third trimester of the academic year 2018-2019 at a technological university in northeastern Thailand. 126 subjects were selected by convenient sampling who are non-English major university students involving this study. 79 females and 47 males are all freshmen whose average age is about 19 years old.

\subsection{Instruments}

The present study employed a mixed method using questionnaires and survey open-ended questions. The adopted questionnaire (Appendix B) measuring English learning motivation was based on Gardner's (1985) Attitude/Motivation Test Battery (AMTB) which has been modified. The adopted L2 WTC questionnaire (Appendix C) was based on Weaver's (2010) L2 WTC questionnaire which has been adapted. The survey 
open-ended questions (Appendix D) were created by the research in terms of Weaver's (2010) Open-ended L2 WTC Questionnaire.

5 males and 5 females freshmen who were non-English majors university students from the same university were invited to complete the questionnaires and open-end questions for the pilot study to see whether they work or not. By using SPSS 17.0 to analyze the collected data from the pilot study, the values for Cronbach alpha of the English Learning Motivation and L2 WTC questionnaires were 0.792 and 0.831 respectively to show that the two questionnaires both are highly reliable. And the values for KMO of the English Learning Motivation and L2 WTC questionnaires were 0.785 and 0.886 to show that they both have high validity.

In order to make Thai students understand the questionnaires and open-ended survey questions and answer clearly, the questionnaires and open-ended survey questions are provided English and Thai version which have been translated from English to Thai with the help of Three Thai teachers of English who know both English and Thai languages very well in Thailand. In addition, student answered the open-ended questions in Thai language to express their meanings clearly.

\subsection{Data Collection}

All of the data collection was conducted during the English class time. Two English teachers helped me collect data from their English class. Before giving them the questionnaires and open-ended questions, the researchers explained the basic concepts involved in the study to them. The intention and purpose of this study were also be clarified to them and written down in the questionnaires.

A consent form written in English was delivered after the previous explanations (Appendix A). The researcher first explained the consent form and about 5 minutes were given to the participants to read the consent form and to raise questions about the study and the questionnaires. Only the students who were willing to participate in the study were delivered the questionnaires after they signed the consent form. The approximate time of the data collection for each class was about 25 minutes. Before the delivery of the questionnaires to the students who have signed the consent form, the English teacher in charge would tell the students that they should finish the questionnaires and open-ended questions independently and are not allowed to talk with each other. 126 copies of questionnaires were distributed and collected back with the English teachers' presence.

\subsection{Data Analysis}

\subsubsection{For the Quantitative Data Analysis}

Descriptive statistics including mean, standard deviation, and standard error of the two questionnaires were provided to understand the levels of students' English learning motivation and L2 WTC including female and male ones'. By using a median split procedure, the subjects whose mean of L2 motivation and L2 WTC is lower than 2.5 are classified into low level group, and those whose mean of L2 motivation and L2 WTC is higher than 3.5 are classified into high level group. And those whose mean of L2 motivation and L2 WTC is between 2.5 and 3.5 fell into intermediate level group.

Independent samples T-test was used to find the difference in the levels of English learning motivation and L2 WTC between female and male students.

Correlation analysis was used to find the relationship between the L2 learning motivation and L2 WTC. In order to understand which variable (integrative motivation and instrumental motivation) can better predict L2 WTC, multiple regression analysis was applied.

\subsubsection{For the Qualitative Data Analysis}

Content analysis was originally meant to be a quantitative method to analyze texts emanating from qualitative studies. It calculated the number of instances that words, phrases and certain grammatical structures occurred in the text. However, this type of analysis was later altered as to make it less reliant on numbers and more on the text itself. Such an analysis determines which themes emerge from a text and how these themes relate to each other. The qualitative categories are therefore not predetermined but are derived inductively from the text itself. Dörnyei (2007) refers to this as 'latent level analysis' which is "a second-level, interpretive analysis of the underlying deeper meaning of the data7" (p. 246). The present qualitative study followed this latent level analysis and the phases were presented for the students responses to the open-ended survey questions. The steps are (a) translate the data into English, (b) pre-coding and color coding, (c) Forming concepts, categories and themes and (d) interpreting the data and drawing conclusions.

\section{Results and Discussion}

Data collected from the questionnaires were analyzed by SPSS version 17.0. In order to understand the level of 
students' English learning motivation including male and female ones', descriptive statistics including mean, standard deviation, and standard error were provided as follows in table 1. Independent samples T-test in Table 2 was used to find the difference on the levels of English learning motivation between female and male students.

Table 1. Descriptive statistics for ELM

\begin{tabular}{lllll}
\hline & $\mathrm{N}$ & Mean & Standard error & Standard deviation \\
\hline ELM & 126 & 3.7496 & .03255 & .36532 \\
ELM of male & 47 & 3.6904 & .41305 & .06025 \\
ELM of female & 79 & 3.7848 & .33150 & .03730 \\
Instrumental M & 126 & 3.8500 & .03017 & .33864 \\
Integrative M & 126 & 3.6492 & .04325. & .48543 \\
\hline
\end{tabular}

Note. ELM for English Learning Motivation, Instrumental M for instrumental motivation, Integrative M for integrative motivation

Table 2. Independent samples T-Test for male and female in ELM

\begin{tabular}{llllll}
\hline & \multicolumn{2}{l}{ Levene's test for equality of variances } & \multicolumn{3}{l}{ T-test for equality of means } \\
& $\mathrm{F}$ & $\mathrm{Sig}$. & $\mathrm{T}$ & $\mathrm{Df}$ & $\mathrm{Sig}(2$-tailed) \\
\hline ELM Equal variances assumed & 1.775 & .185 & -1.4078 & 124 & .162 \\
\hline Note. Significant level, $\mathrm{P}<.05$. & & & & &
\end{tabular}

From the Table 1, it is easy to find that the students' mean of English learning motivation is 3.7496 higher than 3.5 which means that students in total have high motivation to learn English. Although from Table 1 female students' motivation $(M=3.7848)$ is higher than male ones' $(M=3.6904)$, independent samples $T$ test from table showed that there is no significant difference in English learning motivation level between male and female students $(\mathrm{P}=0.162>0.05)$. Besides, as shown in the Table 1 , the average mean scores of integrative motivation and instrumental motivation are 3.6492 and 3.8500, respectively, which means instrumental motivation is higher than integrative motivation among students.

These research findings corresponded to those of the studies of Kitjaroonchai and Kitjaroonchai (2012) on Thai students' motivation toward English learning at an international university in which they found that Thai students had high motivation level of English learning and their instrumental motivation level was slightly higher than integrative counterpart, of Liu (2007) on Chinese students' motivation to learn English at the tertiary level in which she found that students' instrumental motivation was slightly higher than integrative counterpart; of Kyriacou and Zhu (2008) on Shanghai pupil's motivation towards English learning in that their study results indicated that Chinese pupil's motivation was dominated by instrumental reasons concerning career development and the need for examination success; and of Al-Tamimi \& Shuib (2009) on motivation and attitudes towards learning English of Yemeni college students who undertook petroleum engineering at one university of sciences and technology and whose study revealed that the students' instrumental reason for learning English was higher than their integrative reason. From students' responses in open-ended questions, more than $50 \%$ of students without gender difference realized that English is an international language for communicating with people around the world which motivates them to learn English. For example, S41 (female) said that Thai joined the ASEAN therefore it is necessary to learn and use English. S82 (male) said that she will learn English to talk to internationals. S68 (female) thought that English is used for communication with people around the world, so she would learn English well to tell directions for internationals in Thailand. S10 (female) said that she learns English to watch English movies without needing Thai translation. S13 (female) said that mastering English can listen to English songs, watch English movies.

However, the study's results contradicted those of Degang (2010) who studied the motivation toward English learning of Thai students who major in Business English at an English-medium University, in which he found that the students' integrative motivation was slightly higher than their instrumental motivation. The supposition was given that these students' results may be attributed to the rather competitive environment of an English-medium University in the predominantly Thai speaking country in Thailand. One of the reason why 
students have higher instrumental motivation than integrative motivation in this study may be that subjects are all science students for they learn English with more instrumental reasons than integrative ones.

In order to understand the level of students' L2 WTC including male and female ones', descriptive statistics including mean, standard deviation, and standard error were provided as follows in Table 3. Independent samples T-test in Table 4 was used to find the difference on the levels of L2 WTC between female and male students.

Table 3. Descriptive statistics for L2 WTC

\begin{tabular}{lllll}
\hline & $\mathrm{N}$ & Mean & Standard error & Standard deviation \\
\hline L2 WTC & 126 & 3.3426 & .05723 & .64240 \\
L2 WTC of male & 47 & 3.2695 & .80023 & .11673 \\
L2 WTC of female & 79 & 3.3861 & .52779 & .05938 \\
\hline
\end{tabular}

Note. L2 WTC for willingness to communicate in English.

Table 4. Independent Samples T-test for Male and Female in L2 WTC

\begin{tabular}{lllll}
\hline & $\mathrm{F}$ & $\mathrm{T}$ & $\mathrm{Df}$ & $\mathrm{Sig}(2$-tailed) \\
\hline ELM Equal variances assumed & 5.774 & -.985 & 124 & .327 \\
\hline Note. Significant level, $\mathrm{P}<.05$. & & &
\end{tabular}

Note. Significant level, $\mathrm{P}<.05$.

From the Table 3, it is found easily that the students' mean of L2 WTC is 3.3426 between 2.5 and 3.5 which means that students in total have intermediate level of L2 WTC. Although from table 3 female students' level of L2 WTC $(M=3.3861)$ is a little higher than male ones' $(M=3.2695)$, independent samples T-test from Table 4 shows that there is no significant difference in L2 WTC level between male and female students $(\mathrm{P}=0.327>0.05)$. In other words, students, no matter males or females, only have intermediate willingness to communicate in English.

These results are supported by the study of Pattapong (2015) on factors underlying Thai EFL learners' Willingness to Communicate in English in which they found that most of Thai students had intermediate-low level of the use of English in most EFL classrooms in Thailand despite the teachers' best efforts to implement the communicative approach. According to Hofstede's (2001) survey of cross-cultural differences, Thailand was ranked high in collectivism. The analysis of Thai values on social interaction patterns suggests that an evaluation of others on self has a great effect on ones' decision on whether or not to speak in English in EFL classrooms (Pattapong, 2011). Another important characteristic of Thai society is that it is a hierarchical-structured society (Wichiajarote, 1973). Thais feel the need to identify the rank of the persons they are talking to, whether they are 'superior' or 'inferior' to them, reflecting the hierarchical nature of the Thai society. From the students' responses in the open-ended questions, more than $50 \%$ of students said that they are more willing to communicate with friends than teachers for friends are easy to talk and understand. For example, S37 (female) said that friends are easy to ask and reach. S33 (female) said that friends can explain more clearly in Thai to help me out in English problems. S61 (male) said that friends can easily understand each other.

Correlation analysis was used to find the relationship between the English learning motivation, integrative motivation, instrumental motivation and L2 WTC and the results from correlation analysis were shown in Table 5. Multiple regression analysis was applied to find which variable (instrumental motivation and integrative motivation) in English learning motivation can better predict L2 WTC and the results from multiple regression analysis could be found in Tables 6,7 and 8 below.

Table 5. Correlation analysis for the relationship between the English learning motivation, integrative motivation, instrumental motivation and L2 WTC

\begin{tabular}{llll}
\hline & ELM & Instrumental M & Integrative M \\
\hline Pearson Correlation & $.314^{* *}$ & $.298^{* *}$ & $.277^{* *}$ \\
Sig. (2-tailed) & 0 & 0.001 & 0.002 \\
\hline
\end{tabular}




\begin{tabular}{lllll}
\hline L2 WTC & $\mathrm{N}$ & 126 & 126 & 126 \\
\hline Note & &
\end{tabular}

Note. ${ }^{*} \mathrm{p}<.05, * * \mathrm{p}<.001$.

The correlations of L2 WTC with English learning motivation, instrumental motivation, and integrative motivation were $\mathrm{r}=.314, \mathrm{r}=.298$ and $\mathrm{r}=.277$ respectively. English learning motivation showed a significantly positive correlation with L2 WTC $(\mathrm{P}=0.000<.01)$ which means that the higher English learning motivation is, the more willing to communicate in English the students are. Instrumental motivation and integrative motivation both showed significantly positive correlation with L2 WTC with $\mathrm{P}=.001$ and $\mathrm{P}=.002$ respectively. The result suggests that instrumental motivation is probably a better predictor of L2 WTC.

Table 6. Multiple regression analysis for L2 WTC

\begin{tabular}{lllll}
\hline Model & \multicolumn{2}{l}{ Model Summaryb } & & \\
& $\mathrm{R}$ & R Square & Adjusted R Square & Std. Error of the Estimate \\
\hline 1 & $.328^{\mathrm{a}}$ & .108 & .093 & .61179 \\
\hline
\end{tabular}

a. Predictors: (Constant), Instrumental M, Integrative M.

b. Dependent Variable: L2 WTC.

Table 7. ANOVA $b$

\begin{tabular}{lllllll}
\hline Model & Sum of Squares & df & Mean Square & F & Sig. \\
\hline 1 & Regression & 5.547 & 2 & 2.773 & 7.410 & $.001^{\mathrm{a}}$ \\
& Residual & 46.038 & 123 & .374 & & \\
\multicolumn{1}{l}{ Total } & 51.585 & 125 & & & \\
\hline
\end{tabular}

a. Predictors: (Constant), Instrumental M, Integrative M.

b. Dependent Variable: L2 WTC.

Note. ${ }^{*} \mathrm{p}<.05, * * \mathrm{p}<.01$.

Table 8. Coefficients ${ }^{\mathrm{a}}$

\begin{tabular}{llll}
\hline Model & Standardized Coefficients/Beta & $\mathrm{T}$ & Sig. \\
\hline Integrative M & .163 & 1.602 & .112 \\
Instrumental M & .210 & 2.063 & .041 \\
\hline
\end{tabular}

Note. ${ }^{*} \mathrm{p}<.05,{ }^{*} \mathrm{p}<.01$.

From Tables 6 and 7, integrative motivation and instrumental motivation as a whole can significantly predict L2 WTC ( $\mathrm{R} 2=0.108, \mathrm{P}=0.001$ ), accounting for $10.8 \%$ of the variance in L2 WTC. According to table 8, instrumental motivation showed significant regression coefficient $(B e t a=0.210, t=2.063, p=0.041)$ which means significantly accounting for $21 \%$ of the variance in L2 WTC, while integrative motivation showed no significant coefficient $($ Beta $=0.163, t=1.602, p=0.112)$ which can only explain $16.3 \%$ of the variance in $\mathrm{L} 2$ WTC. So it can be concluded that instrumental motivation is a better predictor of L2 WTC compared to integrative motivation in English learning motivation.

These results are validated by the studies of Peng (2007) on Willingness to Communicate in an L2 and Integrative Motivation among Chinese College Students in which they found that students' English learning motivation had strong positively relationship with L2 WTC and integrative motivation can account for a small portion of variation in L2 WTC but instrumental motivation was a strong predictor of L2 WTC, of Liu and Hsu (2008) in which they showed that L2 WTC was significantly related with English learning motivation ( $\mathrm{r}=.32)$, of MacIntyre et al. (2001) and Hashimoto (2002) in which they observed that motivation positively influenced WTC in L2, of MacIntyre et al. (2003) in which L2 WTC correlated very highly with motivation for language 
learning among students with immersion and other intensive program experiences, of Peng (2012) in which she claimed that motivation to learn the foreign language was strongly linked to learners' L2 WTC. From students' responses in the open-ended questions, we also find that more than $90 \%$ of students in total learn English and are willing to communicate in English for instrumental motivation. Specifically speaking, in intermediate L2 WTC group, about $85 \%$ of students learn English for having instrumental motivation (getting a good job, traveling around the world, achieving a high grade) while almost $100 \%$ of students in high L2 WTC group incline to learn English because of instrumental motivation. This further validates the results from quantitative data that the higher instrumental motivation the students have the more willing to communicate in English they are, which clearly corresponds to the results from table 8 that instrumental motivation significantly accounts for more than $20 \%$ of variance of L2 WTC and is a better predictor of L2 WTC compared to integrative motivation. For instance, S80 (male) said that English can be used at work, to apply for a good job and to talk to foreigners. S78 (male) said that he learns English for daily communication at work and for travelling. S11 (female) said that knowing English can find a good job, travelling around the world.

\section{Conclusion}

This study investigated the relationship between university learners' English learning motivation and their willingness to communicate (WTC) in English in an EFL classroom by applying mixed methods. The results can be concluded as follows.

Firstly, all of the university learners have high motivation to learn English. Even though female students have a little higher English learning motivation than male students', there is no significant difference. Students incline to learn English mainly for more instrumental reasons compared to integrative counterparts. These findings are consistent well with the precious studies on learners' English learning motivation in EFL context (Liu, 2007; Kyriacou \& Zhu, 2008; Al-Tamimi and Shuib, 2009; Kitjaroonchai \& Kitjaroonchai, 2012) in which they found that students in EFL context had high motivation towards English learning especially higher instrumental motivation.

Secondly, the university learners in total have intermediate level on their willingness to communicate in English in EFL classrooms. Female students' level of L2 WTC is a little higher than male students', but there is no significant difference. More than $50 \%$ of students are more willing to communicate in English with friends than with teacher for they believe that friends are easier to communicate and understand. These findings further validate the results from Pattapong $(2011,2015)$ that Thai university learners are not strongly willing to communicate in English in classroom especially not with teachers in English. One of the reasons may be rooted in Thai hierarchical nature of the Thai society that teachers are more superior and higher than them so that they feel not easy to communicate in English with teachers.

Thirdly, university learners' English learning motivation has strong positively correlation with their L2 WTC. In English learning motivation, instrumental motivation has stronger positively correlation with their L2 WTC than integrative counterpart. According to the results form the quantitative and qualitative data, instrumental motivation is a better predictor of L2 WTC which means that the higher instrumental motivation the students have, the more willing to communicate in English they are. These findings concerning the relationship between students' English learning motivation and their L2 WTC correspond to the studies of Peng (2007), Liu\&Hsu (2008), Hashimoto (2002), MacIntyre et al $(2001,2003)$ in which they also found that there is strong positively correlation between EFL learners motivation towards English language learning and their willingness to communicate in English and instrumental reasons have more power in motivating students' L2 WTC in EFL classroom

The implications for English teaching in EFL context are presented in the following. To start, teachers should pay much more attention to improving students' integrative motivation compared to their higher instrumental motivation in case their whole motivation towards English learning would be reduced when they realize their instrumental purposes. According to the strong positively correlation between English learning motivation and L2 WTC, it is very likely in the long run that students' willingness to communicate in English would be improved when their integrative motivation are improved. Besides, for students' intermediate willingness to communicate in English in English classrooms, teachers should find more reasons behind this and try best to improve their L2 WTC. Thirdly, because their is no significant difference on male and female students' English learning motivation, L2 WTC, it is not very necessary for teachers to care about male and female students' seats distribution in classroom when teaching. At last, English teachers should establish fair and friendly relationship with students in English classrooms so that they are more willing to communicate in English with teachers

The suggestions for further research on L2 WTC are that different major students and equal number of males and 
females should be put into emphasis in order to get more complete picture of the relationship between English learning motivation and L2 WTC. Secondly, according to the regression analysis of L2 WTC, there may be other variables affecting it besides English learning motivation, so English proficiency, communicative competence, language anxiety, and so on should be taken into account in the future study on L2 WTC.

\section{References}

Al-Tamimi, A., \& Shuib, M. (2009). Motivation and attitudes towards learning English: a study of petroleum Engineering undergraduates at Hadhramout University of Sciences and Technology. GEMA Online Journal of Language Studies, 9(2).

Bennui, P. (2008). A study of L1 interference in the writing of Thai EFL students. Malaysian Journal of ELT Research, 4, 72-102.

Clément, R. (1980). Ethnicity, contact and communicative competence in a second language. In H. Giles, W. P. Robinson \& P. M. Smith (Eds.), Language: Social psychological perspectives (pp.147-154). Oxford, England: Pergamon Press. https://doi.org/10.1016/B978-0-08-024696-3.50027-2

Clément, R., Baker, S. C., \& MacIntyre, P. D. (2003). Willingness to communicate in a second language: The effects of context, norms, and vitality. Journal of Language and Social Psychology, 22(2), 190-209. https://doi.org/10.1177/0261927X03022002003

Degang, M. (2010). Motivation toward English language learning of the second year undergraduate Thai students majoring in Business English at an English-medium university. Master's project M.A. (Business English for International Communication). Bangkok: Graduate School, Srinakharinwirot University.

Dörnyei, Z. (1998). Motivation in second and foreign language learning. Language Teaching, 31, 117-135. https://doi.org/10.1017/S026144480001315X

Dörnyei, Z. (2005). The psychology of the language learner: Individual differences in second language acquisition. Mahwah, NJ: Lawrence Erlbaum Associates. https://doi.org/10.1177/0261927X05281424

Dörnyei, Z., \& Kormos, J. (2000). The role of individual and social variables in oral task performance. Language Teaching Research, 4(3), 275-300. https://doi.org/10.1177/136216880000400305

Dörnyei, Z. (2001). Teaching and Researching Motivation. UK, Harlow: Pearson Education.

Dörnyei, Z., \& Skehan, P. (2003). Individual differences in second language learning. In C. Doughty, \& M. Long (Eds.), The handbook of second language acquisition (pp. 589-630). Malden, MA: Blackwell Pub. https://doi.org/10.1002/9780470756492.ch18

Dörnyei, Z. (2007). Research Methods in Applied Linguistics: Quantitative, Qualitative, and Mixed Methodologies. Oxford University Press, Oxford.

Ellis, R. (2004). Individual differences in second language learning. In A. Davies, \& C. Elder (Eds.), The Handbook of Applied Linguistics (pp. 525-551). Oxford: Blackwell Publishing.

English Proficiency Index Report. (2011). Asia EF EPI ranking.

Gardner, R. C. (1985). Social psychology and second language learning: The role of attitude and motivation. London: Edward Arnold.

Hashimoto, Y. (2002). Motivation and willingness to communicate as predictors of reported L2 use. Second Language Studies, 20(2), 29-70.

Hofstede, G. (2001). Culture's consequences: Comparing values, behaviors, institutions, and organizations across nations. California: Sage.

Kamprasertwong, M. (2010). Willingness to communicate in English speech as a second language: A study of Thai, Chinese, and Dutch Samples. (Unpublished MA dissertation, University of Groningen, Netherland).

Kang, S.-J. (2005). Dynamic emergence of situational willingness to communicate in a second language. System, 33(2), 277-292. https://doi.org/10.1016/j.system.2004.10.004

Kitjaroonchai, N., \& Kitjaroonchai, T. (2012). Motivation toward English Language Learning of Thai Students Majoring in English at Asia-Pacific International University. Catalyst, 7(1), 21-38.

Kormos, J., \& Dörnyei, Z. (2004). The interaction of linguistic and motivational variables in second language task performance [Electronic Version]. Zeitschrift für Interkulturellen Fremdsprachenunterricht. Retrieved fromhttp://www.spz.tu-darmstadt.de/projekt_ejournal/jg-09-2/beitrag/kormos2.htm. 
Kyriacou, C., \& Zhu, D. (2008). Shanghai pupil's motivation towards learning English and the perceived influence of important others. Educational Studies, 34(2), 97-104. https://doi.org/10.1080/03055 690701811099

Liu, M. (2007). Chinese students' motivation to learn English at the tertiary level. Asian EFL Journal, 9(1), 126-146.

Lu, Y., \& Hsu, C-F. (2008). Willingness to communicate in intercultural interactions between Chinese and Americans. Journal of Intercultural Communication Research, 32, 75-88. https://doi.org/10.1080/ 17475750802533356

MacIntyre, P. D. (2007). Willingness to communicate in the second language: Understanding the decision to speak as volitional process. Modern Language Journal, 91, 564-576. https://doi.org/10.1111/ j.1540-4781.2007.00623.x

MacIntyre, P. D., Baker, S. C., Clément, R., \& Conrod, S. (2001). Willingness to communicate, social support, and language learning orientations of immersion students. Studies in Second Language Acquisition, 23, 369-388. https://doi.org/10.1017/S0272263101003035

MacIntyre, P. D., Baker, S. C., Clément, R., \& Donovan, L. A. (2002). Sex and age effects on willingness to communicate, anxiety, perceived competence, and L2 motivation among junior high school French immersion students. Language Learning, 52(3), 537-564. https://doi.org/10.1111/1467-9922.00194

MacIntyre, P. D., Baker, S. C., Clément, R., \& Donovan, L. A. (2003). Talking in order to learn: Willingness to communicate and intensive language programs. Canadian Modern Language Review, 59(4), 589-607. https://doi.org/10.3138/cmlr.59.4.589

MacIntyre, P. D. \& Charos, C. (1996). Personality, attitudes, and affect as predictors of second language communication. Journal of Language and Social Psychology, 15(1), 3-26. https://doi.org/10.1177/ $0261927 X 960151001$

MacIntyre, P. D., Dörnyei, Z., Clément, R., \& Noels, K. A. (1998). Conceptualizing willingness to communicate in a L2: Asituational model of L2 confidence and affiliation. The Modern Language Journal, 82(4), 545-562. https://doi.org/10.1111/j.1540-4781.1998.tb05543.x

MacIntyre, P. D., \& Gardner, R. C. (1991). Methods and results in the study of anxiety and language learning: A review of the literature. Language Learning, 41, 85-117. https://doi.org/10.1111/j.1467-1770. 1991.tb00677.x

MacIntyre, P. D., MacMaster, K., \& Baker, S. C. (2001b). The convergence of multiple models of motivation for second language learning: Gardner, Pintrich, Kuhl, and McCroskey. In Z. Dörnyei, \& R. Schmidt (Eds.), Motivation and second language acquisition (pp. 461-492). Honolulu, Hawaii: University of Hawaii at Manoa, Second Language Teaching and Curriculum Center.

Ministry of Education Thailand. (2004). National Report: Paper presented at the Forty-seventh Session of the International Conference on Education, Geneva.

Oxford, R. (1997). Cooperative learning, collaborative learning, and interaction: Three communicative strands in the language classroom. Modern Language Journal, 81, 443-456. https://doi.org/10.1111/ j.1540-4781.1997.tb05510.x

Pattapong, K. (2011). Cultural impact on learners' willingness to communicate in English in Thai cultural context. Damrong: Journal of the Faculty of Archaeology, 10(2), 141-160.

Pattapong, K. (2015). Complex interactions of factors underlying Thai EFL learners' willingness to communicate in English. PASAA, 49, 105-136.

Peng, J. (2007). Willingness to communicate in the Chinese EFL classroom: a cultural perspective. In J. Liu (Ed.), English Language Teaching in China: New Approaches, Perspectives, and Standards (pp. 250-269). Continuum, London.

Peng, J. (2012). Towards an ecological understanding of willingness to communicate in EFL classrooms in China. System, 40, 203-213. https://doi.org/10.1016/j.system.2012.02.002

Peng, J., \& Woodrow, L. J. (2010). Willingness to communicate in English: a model in Chinese EFL classroom context. Language Learning, 60(4), 834-876.

Weaver, C. (2010). Japanese university students' willingness to use English with different interlocutors. 
Unpublished doctoral dissertation, Philadelphia: Temple University.

Wichiarajote, W. (1973). The theory of affiliative society. Bangkok: College of Education, Prasanmitr. (cited in Steven Piker (1975). The psychological study of Theravada societies). Netherlands: Brill Academic Publishers.

Yashima, T. (2002). Willingness to communicate in a second language: The Japanese EFL context. The Modern Language Journal, 86(1), 54-66. https://doi.org/10.1111/1540-4781.00136

\section{Appendix A}

\section{Letter of Consent}

Dear students:

We are English doctoral students in the School of Foreign Languages in Suranaree University of Technology in Thailand. We are conducting a study about Thai College Students' English learning motivation and willingness to communicate in English classroom and we would like you to take part in this study.

The study will be conducted in your English classroom during the class time. You will be asked to fill out questionnaires and answer some questions for this study. The expected duration of your participation is about 25 minutes. There are no risks or discomforts if you agree to participate in this study. You have the right to withdraw from the study at any time without penalty. By participating in this study you will be giving researchers and educators valuable information for teaching English. The records of this study will be kept private and confidential to the extent permitted by law. Research records will be stored securely and only the researcher will have access to the records.

If you have any questions concerning this study, you can contact us at maxxjxnu@163.com

Thank you for your participation. Best wishes to you.

Sincerely,

Mr. Xingxing Ma

I have read the above information. I agree to participate in the study.

(signature)

(date)

\section{Appendix B}

\section{English Learning Motivation Questionnaire}

Directions: This questionnaire contains 20 items of situations. Please make your choice with " $\mathrm{X}$ " in the appropriate boxes which you may feel from 1 to 5 in each situation. There is no right or wrong answer. Your own choice is only that we want. We will use the data from the survey only for research and promise to keep it confidential.

1=Strongly Disagree $\quad 2=$ Disagree $\quad 3=$ Neither disagree nor agree(Neutral) $\quad 4=$ Agree $\quad 5=$ Strongly Agree

Table B1. English learning motivation

\begin{tabular}{llllll}
\hline Items & 1 & 2 & 3 & 4 & 5
\end{tabular}

1. Learning English enables me to understand English books, movies, pop music and so on.

2. I use English mainly for class assignments and exams.

3. Learning English enables me to better understand and appreciate the way of life of foreigners.

4. I simply use the English from English textbooks and do not really express myself when speaking or writing in class.

5. Learning English enables me to keep in touch with foreign friends.

6. I am only interested in reading English textbooks for my university study, not other 
English materials such as English newspaper, English magazine.

7. Learning English enables me to discuss interesting topics in English with the people from other countries.

8. Learning English helps me get a good job in the future.

9. Learning English enables me to shift my knowledge to foreigners, such as giving directions to the tourists when they are lost on the way.

10. I am more interested in furthering my higher education than learning English language itself.

11. Learning English enables me to participate freely in academic, social, and other activities among other cultural groups.

12. Learning English is important for traveling abroad.

13. Learning English enables me to behave like native English speakers: such as imitating English accent and using original English expressions.

14. Learning English is important for making me a knowledgeable and educated person.

15. Learning English enables me to appreciate English arts and literature.

16. Learning English is important for helping me search for information and materials in English on the Internet.

17. Learning English helps me to become an open-minded and social persons like English speaking people.

18. Being proficient in English can lead to more success and achievements in career and life.

19. I decide to learn English as best as I can to achieve high proficiency.

20. Being proficient in English makes other people respect me.

\section{Appendix C}

\section{Willingness to Communicate in English Questionnaire}

Directions: This questionnaire contains 18 items of situations. Please indicate with " $\mathrm{X}$ " how willing you are to communicate in English in your English class. Please write down " $\mathrm{X}$ " in the appropriate box from 1 to 5 (with meanings shown below) to respond to the situations. There is no right or wrong answer. Your own choice is only that we want. We will use the data from the survey only for research and promise to keep it confidential.

$1=$ always unwilling $2=$ sometimes willing $3=$ willing half of the time

$4=$ usually willing $\quad 5=$ always willing

Table C1. Willingness to communicate in English

\begin{tabular}{lrrrrr}
\hline Items & 1 & 2 & 3 & 4 & 5
\end{tabular}

1. Greet classmates in English

2. Say "Thanks" in English when someone lends me a pen or something else.

3. Tell my friends in English about the story of a TV show I saw.

4. Read out a dialogue in English from the English textbook.

5. Translate Thai expressions into English by speaking in English class.

6. Ask someone my own questions in English.

7. Ask someone the questions from English textbooks in English.

8. Do a role-play in English at my desk (such as one plays customer ordering food, the other one play waiter in the restaurant).

9. Do a role-play in English in front of the class (such as one plays customer ordering food, the other one play waiter in the restaurant).

10. Give a short speech in English about my hometown with notes in English class. 
11. Give a brief self-introduction in English without notes in English class.

12. Ask someone in English to repeat what they have just said in English because you did not understand in English class.

13. Ask someone in English the meaning of the English word you do not know in textbook in English class.

14. Ask someone in English how to pronounce an English word you do not know in textbook in English class.

15. Ask someone in English how to say a phrase you know how to say in Thai but not in English in English class.

16. Discuss the topics of textbook with classmates in English in English class.

17. Ask English teacher for clarification in English when I am confused about a task in English class.

18. Participate in a debate in English in English class.

\section{Appendix D}

\section{Open-ended survey questions (English version)}

1. What are your reasons for learning English? choose one or more. ( )

a. It will be useful in getting a good job.

b. It will help me understand the culture related to other countries.

c. I will need English for my career in the future.

d. I would like to go to study in English-speaking countries.

e. I would like to become friends with some English-speaking people.

f. It will make me a more knowledgeable person.

g. It will help me if I travel.

h. It is a required course in the school.

i. It will help me to please my parents.

Other reasons (you can write down your reasons in Thai language)

\section{You can answer from 2 to 7 in Thai language}

2. Are you willing to use English in English class? Please give reasons or examples to support your answer.

3. Is there someone special that you want to use English with in your English class? Please give reasons or examples to support your answer.

4. What factors do you think influence your willingness to use English in English class?

5. Who do you talk to if you have a question about English in English class? Why do you want to talk to that person?

6. How do other classmates influence your willingness to use English in your English class?

7. What motivates you to speak English with different people in your English class?

\section{Copyrights}

Copyright for this article is retained by the author(s), with first publication rights granted to the journal.

This is an open-access article distributed under the terms and conditions of the Creative Commons Attribution license (http://creativecommons.org/licenses/by/4.0/). 